Metodički obzori 6(2011)1

Original scientific article

UDK: 372.47

Received: 14. 12. 2010.

\title{
SOLVING REALISTIC PROBLEMS IN THE INITIAL INSTRUCTION OF MATHEMATICS
}

\author{
Mara Cotič, PhD, associate prof. \\ University of Primorska, \\ Faculty of Education Koper (Slovenia), \\ e-mail: mara.cotic@pef.upr.si \\ Darjo Felda, MSc, Senior Lecturer \\ University of Primorska, \\ Faculty of Education Koper (Slovenia) \\ e-mail: darjo.felda@pef.upr.si
}

\begin{abstract}
A b s tract
Mathematical literacy has been developed through a holistic approach to teaching and learning: through researching activities, solving problems of every day life, by involving actual contents and contemporary technologies. In the theoretical part of our study we present the model of teaching and learning strategies of realistic problems that we, the authors of this article, had set for the needs of the study. Modelling plays an extremely important role in the solving of realistic problems. The model we created included four types of realistic problems taken out of every day life and which should be solved by pupils at the beginning of their schooling. These are as follows: realistic problems not containing sufficient data for the solution; realistic problems containing more data than needed for the solution; realistic problems with multiple solutions; realistic problems containing contradictory data and no solution.

In the empirical part we present the results of the research: by application of adequate teaching and learning of mathematics we can develop children's abilities for solving realistic problems.
\end{abstract}

Key words: instruction of mathematics, problem situation, realistic problems, strategies of solving problems, modelling

\section{Introduction}

»It is not easy to define mathematics as science without having to refer, as L. Wittgenstein did, to tautology: mathematics is something that people do, think and know. As R. Hersh says, in mathematics we deal with a special kind of ideas and concepts spread throughout the society, which brings us to iterative and peopleindependent results « (Tomšič et al., 2002). 
In the most general sense mathematical instruction is dedicated to the establishment of a conceptual apparatus and to recognition and learning of procedures which make it possible for an individual to get involved in the above mentioned system of mathematical ideas and, consequently, to be included into the culture we live in. This is also true for primary school mathematical instruction which additionally deals with fundamental and commonly important mathematical concepts. However, this must be done in compliance with children's cognitive development, their abilities, personal traits and life environment.

From the first days of their schooling children have to learn what mathematics is composed of, how it is formed and how it is used. It is not enough that children »absorb « it and practice routine mathematical examples.

It has quite often been underlined that mathematical instruction should develop the following aspects of learning: researching, problem solving, creative thinking, data processing, logical conclusion and result assessment.

However, many people do not consider mathematics to be creative, particularly if they experience learning mathematics and mathematical activities as memorising certain facts and rules and execution of repeated algorithms until they memorise the »mechanical « proceedings, regardless whether they understand what they are doing. In order to make learning mathematics creative, children should be involved in practical solving of realistic problems or certain other mathematical problems which have several possible paths to solution. From time to time it is necessary to challenge children by presenting them with the so called research problems which have multiple solutions and various possible solving strategies. Children often find original considerations and combinations on their pathway to solution, which they are supposed to exchange and discuss with their schoolmates thus creating new ideas which will enrich the »mathematical offering $\ll$.

Creative researching and problem solving are an excellent way of developing mathematical concepts, and many times also a useful tool to consolidate procedures. Of course, researching and problem solving first of all »sharpen« the strategies, in the mathematical context often known as the so called mental skills or logical conclusions. In this reference, pupils:

- put questions and presume potential conclusions,

- select strategies and representations,

- use their mental skills,

- prove or refuse statements,

- critically check, verify and assess their work,

- develop patience and endurance in order to find the solution (ACME, 2008).

The enumerated skills are not significant only for mathematics and mathematical activities. We attribute mathematics a specific position when we speak about logical thinking and argumentation, but the so called deductive processes and conclusion making are also present elsewhere, e.g., in natural sciences and the Slovenian language courses. We can use the acquired knowledge and adequately developed skills in various other areas. 


\section{Realistic problems}

At the beginning of schooling the realistic problems that pupils solve have to be very simple. Several researches have drawn attention to the difficulties of pupils in solving various problems. Difficulties in most cases lie in the textual understanding of the problem and in searching for the adequate mathematical contents, because pupils purely accidentally deal with the given data and do not respect their connection with a realistic context. Mistakes made during problem solving are not a consequence of lack of experience - it turns out that not even success in solving »traditional « problems improves significantly although solving is repeated several times (Renkl, Stern, 1994).

Realistic problems are in most cases solved by mathematisation of the situation, i.e.:

- by building up a mathematical model according to the adequate realistic situation and/or to an every day life situation,

- by solving a mathematical problem we had established,

- by transferring the solution of a mathematical problem which suits a mathematical model to a realistic environment.

The greatest obstacle in solving realistic problems is the establishment of a mathematical model, as this requires the knowledge of the context of a realistic problem situation and possession of a certain degree of creativity (Winter, 1994). An obstacle not to be overlooked is also the last step in solving a realistic problem which even pupils of Primary School higher grades are not aware of.

Example: 26 people have registered for a trip. They agreed to go by car, each car carrying 4 people. How many cars are needed to go for the trip?

Several pupils believed that the correct answer was 6.5 cars. If we reminded them to check whether their answer was correct, they mostly verified the correct calculation and claimed that they had divided correctly. Precisely for that reason we need to have a conversation with them to make them aware of the real situation. Only by appropriate explanation of the solving procedures, and not only by verifying their calculation and other procedures of solving the mathematical model, pupils can be able to get fully aware of the problem situation and to transfer the mathematical result into the realistic environment.

We can find schemes in the literature which indicate how solving realistic problems should be carried out. By mathematisation and adequate modelling we are expected to provide transfer from a real situation to a mathematical domain where the problem, translated to mathematical language, can be solved and then the mathematical solution is interpreted in the language of the real problem situation (Müller, Wittmann, 1984). 


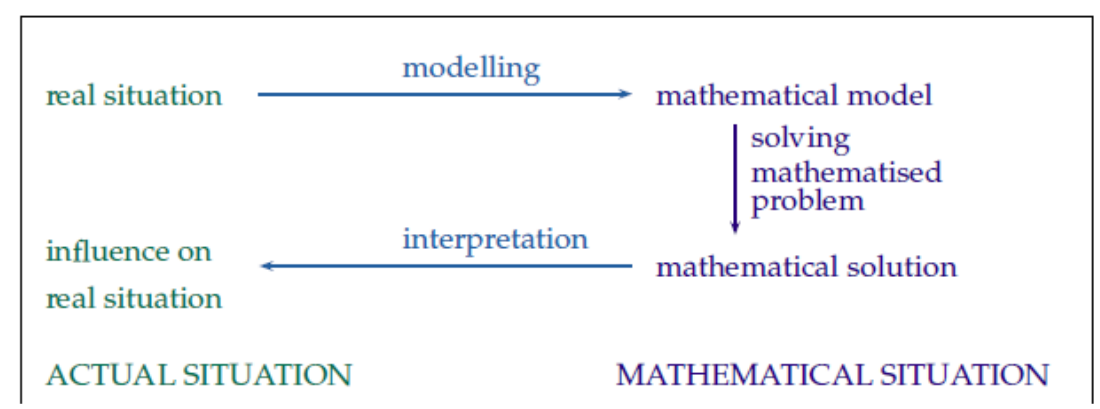

Scheme 1: Solving a realistic problem

If we try to understand why many children have difficulties with standard textual exercises presenting a mathematical problem, although it is necessary to implement »only « a well trained procedure, we have to make a research into how an adequate mathematical model is developed. Pupils of early schooling age do not experience mathematics as a tool for solving realistic problems. To them mathematics is a kind of presentation of multiple things and/or objects, for example, balls, cubes, sticks, etc., with numbers. In fact, for them the situation of modelling is reversed, as shown by illustration below (Peter-Koop, 2004).

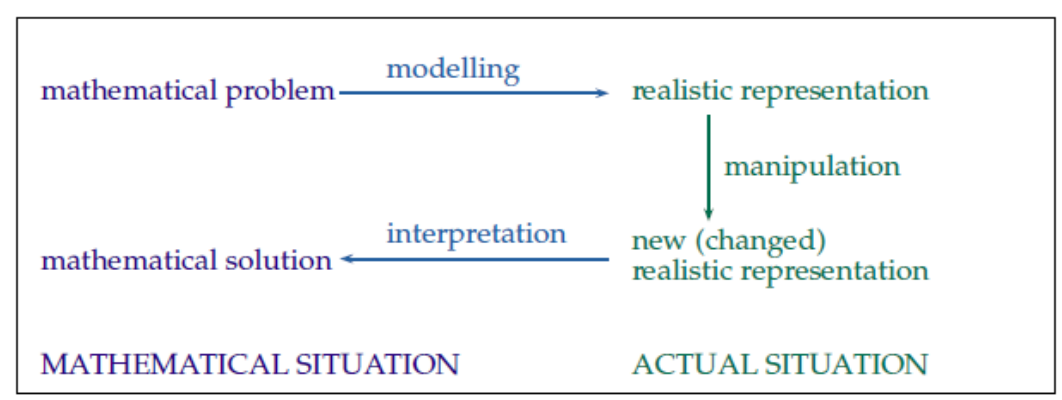

Scheme 2: Connection between actual and mathematical situation

Simple subtraction calculations, e.g. $7-3$, are presented at the beginning of schooling by means of a drawing or a "game", in which the calculation is put in a real context, for example: There were 7 coloured pencils on the table. Ajda took three coloured pencils. How many coloured pencils were left on the table?

Therefore, if at the beginning there are 7 coloured pencils on the table and somebody takes 3, 4 coloured pencils remain. By manipulating the real situation a new real situation is created and this represents the result of subtraction. What is in focus here is not the manipulation with mathematical objects, but the manipulation with the real objects. This means that »standard « textual exercises are not the most appropriate to develop mathematical modelling since the text itself leads to the selection of adequate mathematical operation and mathematical procedure, and it is not necessary to 
search for or to make a research on the links between a real problem situation and mathematics.

The development of mathematical literacy requires more demanding problems which would represent a challenge to pupils. At the beginning of their schooling it is better for pupils to solve such problems in smaller groups, since in a constructive engagement they are able to find more suitable solving strategies. At the same time they expose possible critical points through their conversations and find an optimal solution. In this way, each individual can acquire experience and build up his/her mathematical literacy.

The problems of the real world, suitable to the pupils' age group, should not contain so many numerical data which would turn pupils away from the analysis of a given problem situation and redirect them to calculation and searching for arithmetic algorithms. The data should preferably be given in a descriptive way directing pupils towards assessment and rough calculations as well as searching for and collecting adequate data. Problems should be sufficiently "open" in order to demand from pupils, in their solving procedures, argumentative decisions according to the mathematical model they are using (Peter-Koop, 2004).

Of course, it is necessary to emphasise the real situation for the development of mathematical literacy and not the problems from which we cleaned the "unnecessary" situational elements. We cannot find such problems in the every day life. The problems of every day life most often require a thorough reflection; it is necessary to pull out adequate data and search for appropriate solving strategy, leading to the mathematisation of the problem. Mathematical solution has to be verified afterwards, as it is not obvious that it matches with the every day life situation. The process of solving this kind of problem was illustrated by Blum and Leiss (2007), giving the following display:

Following the above scheme someone solving a realistic problem first of all builds up a situation model. The model reflects understanding of the real situation; it thus indicates how the person solving the problem actually sees and experiences the real situation, as described in the problem. The situation model depends on each individual, on his/her personal understanding of the real situation and on the experiences he/she has with similar real situations. It is not necessary that the model actually fits the situation, as it often happens that pupils, in particular at the beginning of their schooling, are not sufficiently attentive to all the circumstances indicated by the given realistic problem.

Usually, the real situation is complex and the model has already become a slightly simplified version in which the person solving it leaves aside certain information and concentrates only on those which are indispensable for the solution of a given realistic problem. The transfer from the real situation to the model does not take place systematically - it is merely a subjective experienced view of the situation, which shows an individual's inclination to a certain kind of dealing with similar situations.

The situation model is the basis for the creation of a realistic model. The solver consciously idealises and simplifies the situation model which, in fact, for him/her is a real situation or the part of the real situation he/she considers to be of key importance for the solution of a given realistic problem. Knowledge and recognition, not 
necessarily of mathematical character or not only arising from mathematics, guide an individual to a realistic model. A realistic model can be presented by an adequate picture or by a description where we are more or less based on the situation model.

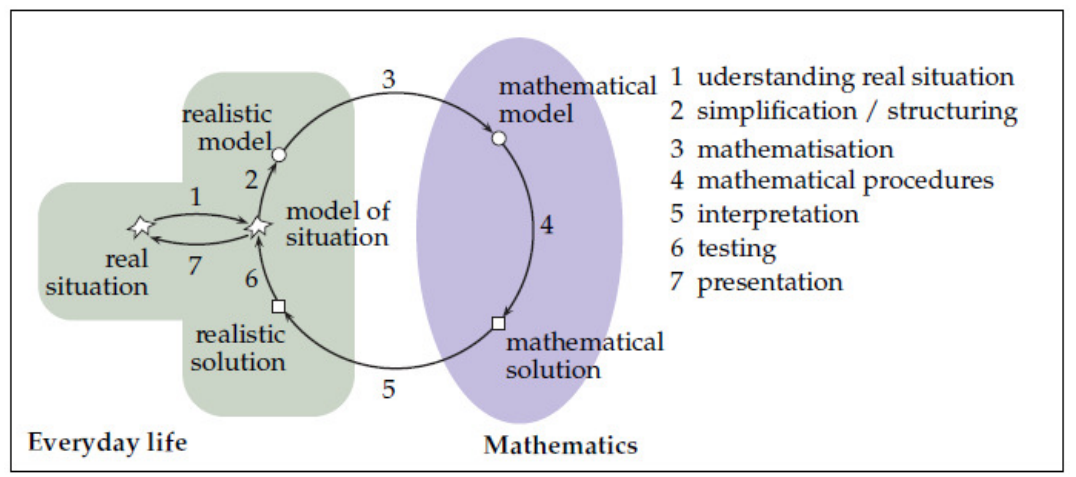

Scheme 3: Process of solving realistic problems

In the mathematisation phase, the line of thoughts is directed from the realistic model to mathematical contents. Adequate pictures and descriptions receive mathematical symbolism and mathematical language from which the mathematical model of real situation arises - the mathematical problem. The solver comes to mathematical solution or mathematical result by using an adequate solving strategy and by selecting mathematical procedures.

By interpreting the mathematical result achieved by means of a mathematical solution of the mathematised realistic model, we are actually returning back to the realistic model which in the meantime has transformed into the realistic solution. The process of interpretation means establishing connections between the mathematical solution and the model of real situation solution.

A person solving a realistic problem faces an important task of verifying and confirming consistency of the realistic solution with the situation model which in fact represents his/her understanding of a given real problem situation. We have noticed many children with intuitive verification of consistency but unable to explain why they adopted a certain solution or why they rejected it. They have relied on their feelings and experience. Naturally, in order to develop mathematical literacy, it is necessary to make pupils used to verifying their realistic solutions and to confirming their decisions which are based on an adequate explanation. Argumentation based on the situation model, as it has been created by the solver, is also important for the exchange of opinions with other solver who have created different situation models. The exchange of opinions means to present solutions to an initial problem situation achieved by several solver who either confirm the identity and similarity of their solutions, or certain discrepancies which require further proceedings on the problem situation. In case there is no interaction among solver it may happen that each individual solver gets »his/her own « solution which has not been sufficiently verified because of the fact that a solver established an incomplete or twisted situation model. 


\section{Empirical part}

\section{The research objectives}

The objectives of the research were to test and upgrade our model of solving realistic problems within mathematical instruction at the lower class level described in the theoretical part. In our research we implemented the process-didactic approach (Žakelj, 2004) of teaching and learning mathematics through problem situations taken out of pupils' life experiences. With our research we tested the model in the teaching practice.

\section{Research hypothesis}

$H$ : Experimental group will be more successful in solving realistic problems with too many data, with insufficient data, with multiple solutions and with contradictory data than the control group.

\section{Research methodology}

Basic research method and researching approach.

In our research we used the pedagogical experiment for the empirical research approach, since it is suitable for teaching novelties that have been introduced into the mathematical instruction. Thus, in our research the causal - experimental method was used.

\section{The experiment model.}

We planned the single-factor model of the experiment with school classes as comparative groups with two modalities. For the group comparison we used the existing classes of the third grade of various primary schools.

The group where we introduced the experimental factor was called the experimental group (EG); the group where teachers were teaching in the »traditional way« was called the control group (CG).

The experimental group was subjected to an entirely experimental treatment which included the following:

- realistic mathematical problems,

- strategies of solving a realistic mathematical problem

- modelling

Experiment sample

134 pupils of the third grade of the Littoral Primary Schools participated in the experiment. Pupils were divided into two groups: the experimental (EG) and the control group (CG). 
66 pupils were included into the experimental group (EG), and 68 pupils into the control group (CG).

\section{Variables}

Variables means all those variables which we used for testing pupils' knowledge in the experimental group (EG) and in the control group (CG). Dependent variables are as follows:

- children's results in realistic problems with too many data,

- children's results in realistic problems with insufficient data,

- children's results in realistic problems with multiple solutions,

- children's results in realistic problems with contradictory data.

The course of the research and data collection.

The research took place in the period of six months in the school year 2008/2009. For the needs of this project we prepared the tests of knowledge (initial and final) and determined their most important characteristics: validity, objectivity, reliability and sensitivity.

\section{Data processing}

Statistical data processing was carried out with the help of the statistical programme package SPSS16. We implemented the Leven test of variance homogeneity and the t-test, in order to learn the differences in the knowledge of mathematics at all levels between the pupils of the experimental group and the control group, at the beginning and at the end of the experiment.

\section{Results and interpretation}

We interpreted the results according to the requirements of transparency and logic of providing evidence, in relation to the pre-set hypothesis. Each results interpretation was accompanied by a table of results. While verifying the hypotheses, we followed the rule that the highest acceptable risk for the rejection of hypothesis was a $5 \%$ error.

At the beginning of the experiment we analysed differences in successful solving of realistic problems, by using the t-test which showed that the differences in the knowledge between the EG and the CG were statistically not significant. 


\begin{tabular}{|c|c|c|c|c|c|c|c|}
\hline \multicolumn{1}{|c|}{ Pupils' results at the second level of knowledge (final test) } \\
\hline \hline Test & Group & $n$ & $\begin{array}{c}\text { Results } \\
\text { in \% }\end{array}$ & $\begin{array}{c}\text { Arithmetic } \\
\text { mean }\end{array}$ & $\begin{array}{c}\text { Standard } \\
\text { deviation }\end{array}$ & Min & Max \\
\hline \hline & $\mathrm{ES}$ & 66 & 73.20 & 3.66 & 1.254 & 0.00 & 5.00 \\
\hline \hline Too many data & $\mathrm{KS}$ & 68 & 47.20 & 2.36 & 1.407 & 1.00 & 5.00 \\
\hline Insufficient data & $\mathrm{ES}$ & 66 & 91.50 & 3.66 & 0.669 & 0.67 & 4.00 \\
\hline \hline & $\mathrm{KS}$ & 68 & 81.25 & 3.25 & 0.952 & 0.00 & 4.00 \\
\hline Multiple solutions & $\mathrm{ES}$ & 66 & 68.63 & 5.49 & 1.895 & 0.25 & 8.00 \\
\hline & $\mathrm{KS}$ & 68 & 45.13 & 3.61 & 2.280 & 0.00 & 7.75 \\
\hline Contradictory data & $\mathrm{KS}$ & 66 & 71.80 & 3.59 & 1.105 & 0.25 & 5.00 \\
\hline
\end{tabular}

Table 1: Basic statistical assessment of the exercises testing the knowledge of solving realistic problems with too many data, insufficient data, multiple solutions and contradictory data in the final test.

The following paragraphs present the analysis of the differences in the success of solving realistic problems between the pupils of the EG and the CG at the end of the experiment.

The analysis of differences in the knowledge of solving realistic problems between the pupils of the experimental group (EG) and the control group (CG) in the final stage.

The main objective of our research was to test the hypothesis that the pupils of the EG, who had received instruction according to the new model of teaching and learning realistic problems, were more successful in solving realistic problems than the pupils from the CG, whose instruction was given in the classical way of teaching and learning problems.

If we compare the differences of arithmetic means of all the variables between the EG and the CG (Table 1), we find out that the EG was more successful in solving all kinds of realistic problems.

By using the Leven test of variance homogeneity and the t-test, we checked what variables resulted in statistically significant differences between the two groups at the end of the experiment.

\begin{tabular}{|l|c|c|c|c|}
\hline \multicolumn{2}{|c|}{ Leven's test of variance homogeneity } & \multicolumn{2}{c|}{ t-test } \\
\hline & $\mathrm{F}$ & $\mathrm{p}$ & $\mathrm{t}$ & $\mathrm{p}$ \\
\hline T2 Too many data & 0.004 & 0.949 & 5.516 & 0.000 \\
\hline T2 Insufficient data & 5.752 & 0.018 & $* 2.995$ & 0.004 \\
\hline T2 Multiple solutions & 0.285 & 0.594 & 5.040 & 0.000 \\
\hline T2 Contradictory data & 0.458 & 0.500 & 2.031 & 0.044 \\
\hline
\end{tabular}

Table 2: Presentation of differences in the knowledge of solving mathematical problems between the EG and the CG in the final test of knowledge

(Note: *the Cochran-Cox approximate method of t-test was implemented). 
Table 2 clearly shows that the two groups statistically significantly differ in all four variables. This confirmed our hypothesis:

The experimental group will be more successful in solving realistic problems with too many data, with insufficient data, with multiple solutions and with contradictory data than the control group.

\section{Conclusions}

With our research we managed to confirm how important and necessary it is to guide and direct pupils of an early schooling age when they are faced with the solving of realistic problems. Pupils who were taught the strategies of solving realistic problems in accordance with our model were more successful in solving all kinds of realistic problems than pupils from the control group where those strategies were not taught.

In order to avoid an excessive influence on children's solving procedures, which are supposed to be established as independently as possible, we offer pupils at the beginning of their schooling less complex problems, allowing them to more easily extract the information and data they need and to create an effective and sufficiently simple situation model. Certainly, we should not prevent pupils from solving realistic problems under the pretext that their knowledge is not effective enough, since they have to constantly develop and upgrade adequate strategies of solving realistic problems where they can implement their knowledge and skills. It is also important to underline that it is necessary to become familiarized with an adequate problem situation and to use the knowledge and experience from every day life if the realistic problem is given as a textual exercise. In particular, pupils at the beginning of their schooling tend to search for numerical data and to use randomly selected operations although the obtained result is completely senseless. Such misplaced sample of solving textual exercises is quite common also in case of senior pupils, since successful solving of mathematical problems in "life" has changed costume and depends merely on good luck and the right selection of a correct operation or procedure, as well as correct data management.

Several researches on ensuring and raising the level of mathematical literacy have proven that it is necessary to introduce certain changes into the teaching of mathematics. Pupils should be more actively involved in conversation which helps them extract their knowledge and understanding of mathematics, their way of thinking and taking conclusions, as well as augmenting the selected methods and procedures of problem solving. Interactive teaching, with all pupils from a classroom being involved, including some group work or individual work, and by introducing pocket calculators while calculating manually and when carrying out mental strategies, proved to be successful (Reynolds, Muijs, 1999). Reynolds and Muijs (1999) have pointed out that weaker results are obtained in lower classes of primary schools where there is a lot of repetition of arithmetic procedures, too much individual work and not enough emphasis on skills in calculating manually. Contrary to that, the main characteristics of the work in more successful classes are as follows: 
- clear teaching lesson structure, good exploitation of time with appropriate challenges, steps and motivation,

- teacher functioning as a moderator,

- permanent interaction between teachers and pupils, monitoring of understanding and misconceptions, as well as constructive help for pupils,

- testing of knowledge and skills, as well as fast recollection of certain concepts,

- use of diverse activities on a certain topic to consolidate and deepen the pupils' knowledge (Reynolds, Muijs, 1999).

\section{References}

ACME (2008). Mathematics in Primary Years. A discussion paper for the Rose Review of the Primary Curriculum, The Advisory Committee on Mathematics Education (ACME). http://www.acme-uk.org/downloaddoc.asp?id=108, 21. januar 2010.

Blum, W., Leiss, D. (2007). How do students and teachers deal with modelling problems?, v: Haines, C. et al. (ur.), Mathematical Modelling: Education, Engineering and Economics, Chichester, Horwood, 222-231.

Müller, G., Wittmann, E. (1984). Der Mathematikunterricht in der Primarstufe, Vieweg, Braunschweig.

Peter-Koop, A. (2004). Fermi problems in primary mathematics classrooms: Pupils' interactive modelling processes, v: Putt, I., Faragher, R., McLean, M. (ur.), Mathematics education for the third millennium: Towards 2010, Proceedings of the 27th annual conference of the Mathematics Education Research Group of Australasia, MERGA, Sydney, 454-461.

Renkl, A., Stern, E. (1994). Die Bedeutung von kognitiven Eingangsvoraussetzungen und schulischen Lerngelegenheiten für das Lösen von einfachen und komplexen Textaufgaben, Zeitschrift für Pädagogische Psychologie, 8(1), 27-39.

Reynolds, D., Muijs, D. (1999). The effective teaching of mathematics: A review of research, School Leadership \& Management, 19(3), 273-289.

Tomšič, G., Cotič, M., Magajna, Z., Žakelj, A. (2002). Učni načrt: program osnovnošolskega izobraževanja. Matematika. Ministrstvo za šolstvo, znanost in šport, Zavod RS za šolstvo, Ljubljana.

Winter, H. (1994). Modelle als Konstrukte zwischen lebensweltlichen Situationen und arithmetischen Begriffen, Grundschule, 26(3), 10-13.

Žakelj, A. (2004). Procesno-didaktični pristop in razumevanje matematičnih pojmov v osnovni šoli : doktorska disertacija. Univerza v Ljubljani, Filozofska fakulteta, Ljubljana. 
Metodički obzori 6(2011)1

Izvorni znanstveni rad

UDK: 372.47

Primljeno: 14. 12. 2010.

\title{
REŠEVANJE REALISTIČNIH PROBLEMOV PRI ZAČETNEM POUKU MATEMATIKE
}

\author{
Izr. prof. dr. Mara Cotič, \\ Univerza na Primorskem, \\ Pedagoška fakulteta Koper (Slovenija) \\ e-mail: mara.cotic@pef.upr.si
}

mag. Darjo Felda, viš. pred.

Univerza na Primorskem,

Pedagoška fakulteta Koper (Slovenija)

e-mail: darjo.felda@pef.upr.si

Povzetek

Matematično pismenost razvijamo $\mathrm{s}$ holističnim pristopom učenja in poučevanja: $\mathrm{z}$ raziskovalno dejavnostjo, reševanjem problemov iz vsakdanjega življenja, vključevanjem aktualnih vsebin in sodobnih tehnologij. V teoretičnem delu raziskave prikazujemo model poučevanja in učenja strategij realističnih problemov, ki smo ga za potrebe raziskave postavila avtorja prispevka. Pri reševanju realističnih problemov ima izjemno pomembno vlogo modeliranje. Model vključuje štiri vrste realističnih problemov, ki izhajajo iz vsakdanjega življenja in naj bi jih učenci reševali na začetku šolanja. To so: realistični problemi, ki nimajo zadostnega števila podatkov za rešitev; realistični problemi, ki imajo več podatkov, kot je potrebnih za rešitev; realistični problemi z več rešitvami; realistični problemi, v katerih so si podatki nasprotujoči oziroma nimajo rešitev. Pri reševanju navedenih problemov ima izjemno pomembno vlogo modeliranje.

$\mathrm{V}$ empiričnem delu predstavljamo rezultate raziskave, da $\mathrm{z}$ ustreznim poučevanjem in učenjem pri otrocih razvijamo njihove sposobnosti za reševanje realističnih problemov.

Ključne besede: pouk matematike, problemska situacija, realistični problemi, strategije reševanja problemov, modeliranje

\section{RJEŠAVANJE REALISTIČKIH PROBLEMA KOD POČETNE NASTAVE MATEMATIKE}

\section{Sažetak}

Matematičku pismenost razvijamo holističkim pristupom učenja i nastave: istraživačkom djelatnošću, rješavanjem problema iz svakidašnjeg života, uključivanjem aktualnih sadržaja i suvremenih tehnologija. U teoretičnom dijelu istraživanja prikazujemo model nastave i učenja strategija realističkih problema kojeg smo za potrebe istraživanja postavili autori izlaganja. U literaturi nađemo sheme koje ukazuju kako bi trebalo teći rješavanje realističkog problema. Kod rješavanja realističkih problema ima izuzetno važnu ulogu modeliranje. Odgovarajućim bi 
modeliranjem trebalo prijeći iz realne situacije u matematičku domenu, gdje se može riješiti problem preveden u matematički jezik, poslije se pak matematičko rješenje tumači u jeziku realne problemske situacije.

Realističke probleme znači najviše puta rješavamo matematizacijom nematematičke situacije odnosno modeliranjem, to jest:

- izgradimo matematički model u odnosu na odgovarajuću realističku situaciju odnosno situaciju iz svakidašnjeg života,

- riješimo matematički problem kojeg smo izgradili,

- rješenje matematičkog problema koje odgovara matematičkome modelu prenesemo u realističku sredinu.

Model koji smo izgradili uključuje četiri vrste realističkih problema koji proizlaze iz svakidašnjeg života i učenici bi ih trebali rješavati početkom školovanja. To su: realistički problemi koji nemaju dovoljnog broja podataka za rješenje; realistički problemi koji imaju više podataka nego što je potrebno za rješenje; realistički problemi s više rješenja; realistički problemi u kojim su podatci suprotni odnosno nemaju rješenja.

U empiričkom dijelu predstavljamo rezultate istraživanja da odgovarajućom nastavom i učenjem matematike kod djece razvijamo njihove sposobnosti za rješavanje realističkih problema. Učenici koji su imali nastavu strategija rješavanja realističkih problema po našem modelu bili su uspješniji od učenika iz kontrolne skupine koji strategije nisu učili kod rješavanja svih vrsta realističkih problema.

Treba istaći da mora učitelj izbjegavati preveliki utjecaj na djetetov postupak rješavanja. U tu svrhu ponudimo učenicima početkom školovanja manje kompleksne probleme iz kojih lakše izljušte one informacije i podatke koji su potrebni za oblikovanje efikasnog i dovoljno jednostavnog modela situacije. Nikako pak ne smijemo učenicima onemogućiti rješavanje realističkih problema tobože da je njihovo znanje još premalo efikasno jer moraju stalno razvijati i nadgrađivati odgovarajuće strategije rješavanja realističkih problema u koje uključuju svoja znanja i vještine.

Ključne riječi: nastava matematike, problemska situacija, realistički problemi, strategije rješavanja problema, modeliranje. 